Ludwig, S. C., N. J. Aebischer, D. Bubb, M. Richardson, S. Roos, J. D. Wilson, and D. Baines. 2018. Population responses of Red Grouse Lagopus lagopus scotica to expansion of heather Calluna vulgaris cover on a Scottish grouse moor. Avian Conservation and Ecology 13(2):14. https://doi. org/10.5751/ACE-01306-130214

Copyright (C) 2018 by the author(s). Published here under license by the Resilience Alliance.

Research Paper

\title{
Population responses of Red Grouse Lagopus lagopus scotica to expansion of heather Calluna vulgaris cover on a Scottish grouse moor
}

\author{
Sonja C. Ludwig ${ }^{1,2}$, Nicholas J. Aebischer ${ }^{1}$, Damian Bubb ${ }^{2,3}$, Michael Richardson ${ }^{1}$, Staffan Roos ${ }^{4,5}$, Jeremy D. Wilson ${ }^{4}$ and David \\ Baines ${ }^{l}$ \\ ${ }^{1}$ Game \& Wildlife Conservation Trust, UK, ${ }^{2}$ Langholm Moor Demonstration Project, UK, ${ }^{3}$ Paragon Ecology, UK, ${ }^{4}$ RSPB Centre \\ for Conservation Science, RSPB Scotland, UK, ${ }^{5}$ Swedish Species Information Centre, Swedish University of Agricultural Sciences, \\ Sweden
}

\begin{abstract}
Loss of heather Calluna vulgaris-dominated moorland in Britain has been associated with long-term declines in Red Grouse Lagopus lagopus scotica, a gamebird of economic importance. We tested whether restoring heather habitat on a grouse moor in southwest Scotland, where heather was previously in decline, improved Red Grouse density, productivity, and survival. We analyzed spatial and temporal relationships between Red Grouse demographic rates, estimated from counts, and habitat variables measured from ground and aerial vegetation surveys. Reductions in sheep Ovis aries grazing and other heather restoration measures (i.e. burning and cutting, and in some areas reseeding of heather following herbicide treatment to reduce grass dominance) increased total heather cover by $10 \%$ and the area of heather-dominated vegetation by $30 \%$ within six years. Prebreeding, and for aerial surveys also postbreeding, densities of Red Grouse were highest in areas with more heather cover (range: $0-92 \%$ ), and prebreeding densities increased more where heather recovery was greatest. However, we found no relationship between heather cover and Red Grouse productivity or survival rates, the latter also when rates were estimated from radio-tagged individuals. Changes in heather cover were not associated with changes in postbreeding densities or survival of Red Grouse, although they were positively related to change in productivity for aerial surveys. Overall, management for Red Grouse had a larger effect on density and productivity than reductions in sheep grazing. This is the first study examining Red Grouse responses in relation to changes in heather cover within the same site, in contrast to previous between-moor comparisons, where other factors may have contributed to variation in Red Grouse demography. Our results suggest that, in the long term, heather restoration has the potential to increase Red Grouse carrying capacity, but realizing this potential first requires improving Red Grouse demographic rates.
\end{abstract}

\section{Population responses of Red Grouse Lagopus lagopus scotica to expansion of heather Calluna vulgaris cover on a Scottish grouse moor}

RÉSUMÉ. La perte de terrains marécageux dominés par la bruyère Calluna vulgaris en Grande-Bretagne a été associée à la baisse de longue date du Lagopède d'Écosse Lagopus lagopus scotica, un oiseau gibier d'importance économique. Nous avons testé si la restauration d'habitat de bruyères sur un terrain marécageux utilisé par les lagopèdes dans le sud-ouest de l'Écosse - où la bruyère était auparavant en diminution - améliorait la densité, la productivité et la survie du Lagopède d'Écosse. Nous avons analysé les relations spatiales et temporelles entre les paramètres démographiques du lagopède, estimés à partir de dénombrements, et les variables d'habitat mesurées au moyen de relevés de végétation terrestres et aériens. La réduction du broutement par le mouton Ovis aries et les autres mesures de restauration de la bruyère (c.-à-d. le brûlage et la coupe, et dans certains endroits le réensemencement de bruyères suivant des traitements par herbicide pour réduire la dominance des herbes indésirables) ont permis d'augmenter de $10 \%$ le couvert total de bruyères et de $30 \%$ la superficie de végétation dominée par la bruyère en 6 ans. La densité de lagopèdes la plus élevée pré-nidification, et aussi postnidification dans le cas des relevés aériens, a été observée aux endroits où le couvert de bruyères était plus étendu (écart : 0-92\%), et la densité pré-nidification a davantage augmenté là où le rétablissement de bruyères a été le plus grand. Toutefois, nous n'avons pas trouvé de lien entre le couvert de bruyères et les taux de productivité et de survie des lagopèdes; c'était aussi le cas pour la survie estimée à partir d'individus munis d'émetteurs radio. Le changement du couvert de bruyères n'a pas été associé à un changement de la densité ou de la survie post-nidification des lagopèdes, bien qu'il ait été associé positivement au changement de productivité pour les relevés aériens. Dans l'ensemble, l'aménagement pour le Lagopède d'Écosse a eu un effet plus grand sur la densité et la productivité que la réduction du broutement par le mouton. Notre étude est la première à examiner les réactions du Lagopède d'Écosse face au changement du couvert de bruyères sur un même site, par opposition aux comparaisons précédentes faites entre divers terrains marécageux, où d'autres facteurs ont vraisemblablement pu contribué aux variations démographiques des lagopèdes. Nos résultats indiquent que, sur un long horizon, la restauration des bruyères a le potentiel d'améliorer la capacité de support du Lagopède d'Écosse, mais pour y parvenir, il faut au préalable travailler à améliorer les paramètres démographiques des lagopèdes.

Key Words: demographic rates; grazing management; grouse-moor management; habitat restoration

Address of Correspondent: Sonja C. Ludwig, GWCT, The Coach House, Eggleston Hall, Barnard Castle, United Kingdom, DL12 0A,

sludwig@gwct.org.uk 


\section{INTRODUCTION}

Habitat loss, driven primarily by changes in human land use and agricultural intensification, is a major threat to biodiversity (Wilcove et al. 1998, Brooks et al. 2002) and has contributed to population declines in many bird species, often interlinked with increased predation pressure in anthropogenic landscapes (Schmiegelow and Mönkkönen 2002, Evans 2004, Wilson et al. 2004, Roos et al. 2018). The restoration of suitable habitat is thus an important management tool for avian conservation and can provide key resources to support sustainable populations (OrtegaÁlvarez and Lindig-Cisneros 2012). In some situations, habitat interventions alone can have marked impacts for ground-nesting species (e.g., McCallum et al. 2018). However, where populations are limited by factors other than habitat, habitat restoration may not necessarily be effective in improving demographic rates and ultimately increasing bird populations (Bro et al. 2004, Schrott et al. 2005, Fletcher et al. 2006).

The Red Grouse Lagopus lagopus scotica (hereafter grouse) is an upland gamebird of economic value in Britain and is widely distributed on moorland dominated by ling heather Calluna vulgaris (hereafter heather; Watson and Moss 2008), a globally rare habitat supporting internationally important plant and animal communities (Thompson et al. 1995). On areas where grouse shooting is the main land use (grouse moors), gamekeepers manage generalist predators, parasites of grouse, and heather habitat to maximize postbreeding grouse densities for shooting (Hudson and Newborn 1995). Typically, grouse prebreeding densities are positively correlated with heather cover (Miller et al. 1966, Pearce-Higgins and Grant 2006). The extent of heather burning, which creates a more varied vegetation structure, has been associated with higher prebreeding densities (Tharme et al. 2001) and higher productivity and postbreeding densities (Robertson et al. 2017a). However, these findings are based on between-moor comparisons, where other factors such as intensity of predator or parasite control may have contributed to betweenmoor variation (Robertson et al. 2017a).

In many parts of the British uplands, heather cover declined during the 20th century following increases in grazing by sheep Ovis aries and afforestation (Thompson et al. 1995, Fuller and Gough 1999, Robertson et al. 2001). The loss of heatherdominated moorland has been associated with long-term declines in the numbers of grouse shot (Thirgood et al. 2000a, Robertson et al. 2017b), which are correlated with grouse abundance (Cattadori et al. 2003), and reductions in the extent of grouse moor management (Robertson et al. 2001). These changes in upland land use also contributed to declines of other groundnesting moorland birds in Britain such as Black Grouse Lyrurus tetrix (Baines 1996, Calladine et al. 2002), Eurasian Curlew Numenius arquata, and European Golden-Plover Pluvialis apricaria (Amar et al. 2011, Douglas et al. 2014).

Changes in habitat extent and quality may influence predation rates, with habitat degradation making grouse and other birds more vulnerable to predation (Evans 2004, Whittingham and Evans 2004). On heather moorland, a reduction in the extent and nutritional quality of heather may force grouse to spend more time foraging and be less vigilant, while a reduction in heather cover may make them more visible and accessible to predators (Redpath and Thirgood 1997). Grouse preferentially forage at the boundaries between different-aged heather stands for easy access to both nutritious young heather and adjacent cover (Palmer and Bacon 2001). Where interactions between habitat change and predation contribute to population declines, it may be possible to reduce the impact of predation through habitat restoration or management (Evans 2004). Increasing the amount of suitable habitat and reducing habitat fragmentation will generally enhance resources for prey species (Andrén 1994). Management of vegetation structure and cover may also affect vulnerability to predators and can be used to increase productivity and survival (Rands 1988, Taylor et al. 1999, Whittingham and Evans 2004).

Here, we examine spatial and, for the first time, temporal relationships between habitat and grouse demography on a moor where heather has been in decline since at least the late 1940s (Thirgood et al. 2000a). First, we quantify the effect of heather habitat restoration measures in increasing heather cover. Second, we test whether heather cover in this area is positively associated with density, productivity, and survival of grouse. We predict that (i) grouse density, productivity, and survival will show a positive spatial correlation with heather cover; (ii) temporal increases in heather cover will be linked to increases in grouse density; and (iii) temporal increases in heather cover, combined with its management by burning or cutting, will improve habitat conditions, which will be associated with increases in grouse productivity and survival. Finally, we test the relative importance of sheep grazing intensity, which affects heather cover, and management for grouse, which includes predator and parasite control and heather burning/cutting, in explaining variation in grouse demographic responses.

\section{METHODS}

\section{Study area}

\section{Location and land cover}

The study was conducted on Langholm Moor, southwest Scotland, as part of the Langholm Moor Demonstration Project (LMDP; Ludwig et al. 2017) between 2007 and 2016. In addition, for one correlational analysis between grouse density and sheep grazing intensity, we also included data collected between 2000 and 2017 (see below). The 42-km² study area (Fig. 1; defined by a 500-m buffer around the outer boundaries of the grouse count areas) was dominated by heather moorland, comprising mixed heath and bog habitats. This area was surrounded by a $73-\mathrm{km}^{2}$ buffer zone, where heather previously dominated, but had been lost through overgrazing by sheep and is now chiefly acid grassland (Thirgood et al.2000a), together with a mix of improved enclosed grass fields, commercial coniferous plantations, and mixed deciduous woodland (Land Cover Map 2007; Morton et al. 2011). Thus, Langholm Moor is an isolated heather moor some $30 \mathrm{~km}$ from the nearest other grouse moor and not part of a wider contiguous moorland area managed for grouse. Given that young female grouse disperse on average less than $1 \mathrm{~km}$ (Warren and Baines 2007), we regarded Langholm as a closed population, where immigration was minimal and population growth depended on productivity and survival rates within the study area.

\section{Changes in management over time}

Langholm Moor was managed for "driven" grouse shooting (for description of different shooting styles see Sotherton et al. 2009) 
Fig. 1. Habitat types in study area and buffer zone with location of the Red Grouse (Lagopus lagopus scotica) count blocks $(\mathrm{N}=10)$ and transects $(\mathrm{N}=18)$. "Other" consists mainly of improved grassland, arable, and built-up areas. LCM2007 (C) NERC (CEH) 2011. (C) Crown Copyright 2007, OS Licence no. 100017572. (C) third party licensors.

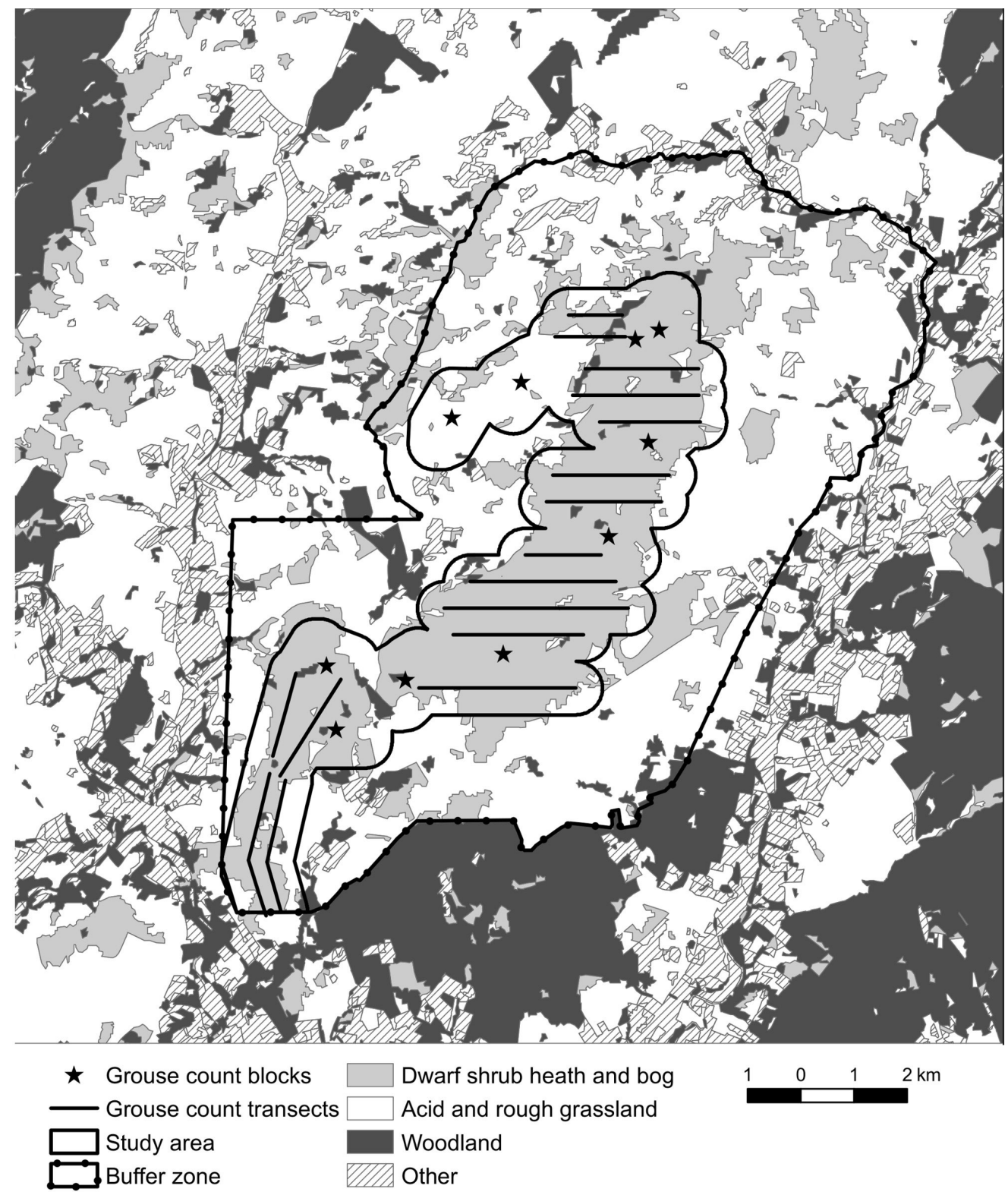

until 1999, with on average $1815( \pm 176 \mathrm{SE})$ grouse shot per annum between 1950 and 1996 (Thirgood et al. 2000a), after which shooting ceased. Declining numbers of grouse shot in the second half of the 20 th century coincided with a $48 \%$ decline in heatherdominated moorland between 1948 and 1988 (Thirgood et al. 2000a). However, rates of heather decline were less severe within our current study area than in the buffer zone (Thirgood et al. $2000 a$ ), and reductions in preshooting grouse densities between 1991 and 1996 were attributed to predation by increasing numbers of Hen Harriers Circus cyaneus and Peregrines Falco peregrinus, rendering shooting economically unviable (Redpath and Thirgood 1999, Thirgood et al. 2000a). Declines in heather cover continued until at least 2007. Between 2000 and 2007, the moor was no longer managed for grouse shooting, although some limited heather burning and predator control took place (Baines et al. 2008), and sheep grazing was the primary land use.

From 2008 to early 2016, grouse-moor management was reinstated to restore and manage the heather habitat and increase grouse numbers sufficiently to resume economically sustainable 
shooting, while maintaining a viable Hen Harrier population (Ludwig et al. 2017). From 2008, five gamekeepers were employed to control generalist predators such as red fox Vulpes vulpes, Carrion Crow Corvus corone, weasel Mustela nivalis, and stoat M. erminea within the wider $115-\mathrm{km}^{2}$ area, i.e., study area plus buffer zone. Raptors were fully protected, and all Hen Harrier broods were provided with diversionary food (Redpath et al. 2001, Ludwig et al. 2018a). The gamekeepers provided medicated grit to grouse between 2008 and 2014 to control the endoparasitic worm Trichostrongylus tenuis, which can reduce grouse breeding success and survival (Hudson et al. 1998, Newborn and Foster 2002). To facilitate heather regeneration and increase heterogeneity in the age and structure of heather cover, the gamekeepers also conducted heather management, burning patches of heather (mean size \pm SE: $0.40 \pm 0.01$ ha, $N=1,071$ ) between 1 October and 15 April and cutting strips 2-3 m wide and of varying length with a tractor-drawn flail mower.

From spring 2011 onward, sheep grazing ceased on $39 \mathrm{~km}^{2}$ of degraded moorland to facilitate heather restoration, with grazing having already ceased on a further $7.4 \mathrm{~km}^{2}$ in 1990 . In addition, a local population of feral goats Capra aegagrus hircus was reduced from over 500 to around 100 individuals by 2011 . Heather was reseeded on 300 ha of previously grass-dominated moorland in 2009 and 2010, preceded by herbicide treatment and burning or cutting, to increase heather recruitment and growth.

\section{Data collection}

\section{Grouse counts}

Grouse were counted within ten $0.5-\mathrm{km}^{2}$ blocks, representative of the moorland habitat (Redpath and Thirgood 1997; Fig. 1). Within each block, the observer walked parallel transects $150 \mathrm{~m}$ apart (mean transect length/block: $3.3 \pm 0.2 \mathrm{SE} \mathrm{km}$ ), while a pointing dog quartered the ground on either side of the transect searching for grouse. From 2008, grouse were also counted on 18 line transects (mean length: $2.0 \pm 0.2 \mathrm{SE} \mathrm{km}$ ), located outside the $0.5-\mathrm{km}^{2}$ blocks and spaced $500 \mathrm{~m}$ apart across the heather habitat. Combined transect length was $68.4 \mathrm{~km}$, of which $83 \%$ was situated in areas where sheep grazing ceased in 2011 and 9\% where grazing had ceased in 1990.

Grouse were counted in spring (March/early April) to estimate prebreeding densities, and again in summer (July/early August) to estimate postbreeding densities and breeding success. Grouse generally started incubation in late April, with chicks hatching in late May. We used line-transect distance sampling to account for variation in search effort and detection probability between dogs (Buckland et al. 2001). When grouse were located, the number of birds and their perpendicular distance to the transect line was measured. Data for each count period in each year were analyzed separately using the program DISTANCE 6.0 (Thomas et al. 2010) to derive detection probabilities, expressed as effective strip widths (ESW, i.e., the transect width effectively searched by the dog). These were then used to calculate grouse densities for each block or transect using the equation: grouse $\mathrm{km}^{-2}=$ total grouse counted/(transect length x ESW) (Warren and Baines 2011).

Grouse counted while in family groups (coveys) in summer were aged as juvenile or adult according to size and plumage freshness to estimate productivity (young adult ${ }^{-1}$ ). Changes in numbers of adult grouse counted between spring and summer (July adult density/spring density) were used to estimate a rate of apparent adult summer survival, and changes during the winter (spring density in following year/July density) were used to estimate a rate of apparent winter survival. The term "apparent" reflected the possibility that grouse moved between blocks or transects, so survival rates based on counts included local immigration/ emigration. This contrasted with "true" survival estimates obtained from radio-tagged individuals (see below).

\section{Grouse radio-telemetry}

Between 2011 and 2016, 157 grouse were dazzled at night in autumn and winter using a lamp, caught in a hand-held net, and fitted with radio-transmitters with motion-sensitive mortality sensors. These birds were monitored remotely for survival weekly and located and flushed once or twice per month. Deaths were confirmed by recovering the tags and any carcasses or remains. Mortality rates of radio-tagged birds averaged 30\% during summer and 39\% during winter and did not differ from estimates derived from counts, suggesting no detrimental effect of tagging (Ludwig et al. 2018b). The mean $x$ and $y$ coordinates from all birds with $\geq 4$ flushing locations (mean \pm SE: $10 \pm 0.3$, range 4 21) and a known fate in each summer (April-September) and winter (October-March) were used to estimate the center point of each bird's summer and winter home range following Thirgood et al. (2002). We analyzed 183 seasonal home ranges from 80 individuals with a $95 \%$ core area of $6.1 \pm 0.4 \mathrm{SE}$ ha (calculated as convex polygons in Ranges 9; Kenward et al. 2014), and a 50\% core area of $0.5 \pm 0.04 \mathrm{SE}$ ha. Home ranges were classified according to whether their occupants survived the summer $(\mathrm{n}=$ 65 home ranges, 51 individuals) or winter ( $n=72$ home ranges, 55 individuals), or whether they died during summer $(n=27)$ or winter $(n=19)$. Individual birds that survived several summer and winter seasons were included in analyses for each of those seasons.

\section{Ground vegetation surveys}

We measured heather cover using ground surveys within the 10 grouse count blocks. Bell heather Erica cinerea was not recorded during ground surveys and cross-leaved heath Erica tetralix was largely subdominant when present, therefore we based all analysis on ling heather $C$. vulgaris. Ground vegetation surveys were conducted during late autumn/winter, first in 2007 before grousemoor management resumed, and repeated at the same time of year in 2012 and 2015. Within each block, 50 (2007) or 100 (2012, 2015) points were sampled at equal intervals along each of two $1-\mathrm{km}$ transects. At each sample point, the dominant, i.e., most abundant, plant species and its height, the presence of other species, and whether the vegetation was recently burned or cut (charred black coloration, presence of grey burned heather stems or regenerating heather up to $10 \mathrm{~cm}$ in height) was recorded within a $30-\mathrm{cm}$ quadrat centered on the point. We calculated heather presence and heather cover in each block as the proportion of points where heather was either present or dominant, respectively, together with the mean and variance in heather height. An index of heather management intensity was calculated as the proportion of sample points at which heather had been recently burned or cut. Because vegetation cover may also vary in relation to vegetation density, we measured density at standing grouse head level by placing a cane, marked with tape at $22 \mathrm{~cm}$ height, vertically into the sward at the sample point. Vegetation density was 
calculated as the proportion of points where the tape was obscured by vegetation, viewed from the perspective of the observer holding the cane at arm's length. The sampling regime provided reasonably precise measures of vegetation characteristics except for heather management intensity, which was very low and recorded as $<2 \%$ in over half of blocks (see Table A1.1 in Appendix 1).

Following Thirgood et al. (2002), we measured the vegetation in the home ranges of radio-tagged grouse along four $100-\mathrm{m}$ transects in the cardinal directions from the center. Along each transect, five $2 \times 2-m$ quadrats were placed at 20-m intervals, giving a total of 20 quadrats per home range. In each quadrat, we estimated the percentage cover of heather and the percentage cover of recently managed heather (burnt or cut) to the nearest $5 \%$, and measured vegetation height. To ensure reasonable temporal comparability between vegetation and home-range occupancy in a recovering habitat, all vegetation data were collected within 18 months of the home range being occupied by the radio-tagged individual. The sampling regime provided reasonably precise measures of vegetation characteristics except for heather management intensity, exactly as for the blocks (see Table A1.1 in Appendix 1).

\section{Aerial vegetation surveys}

Aerial photographs from April 2009 and June 2015 (C) Scottish Natural Heritage/Getmapping plc) were used to estimate changes in heather cover across all grouse count blocks and transects, and also across the wider area (study area and buffer zone). Each 1$\mathrm{km}^{2}$ grid square within the project boundary was divided into four subplots of 25 ha $(500 \times 500 \mathrm{~m})$, which were assigned to either study area or buffer zone. Following Redpath and Thirgood (1997), a 1-ha (100 x 100 m) grid was laid over each 25-ha subplot and heather cover was categorized in each hectare cell to the nearest $10 \%$. We then estimated mean heather cover (mean percentage cover across all 1-ha squares) in 2009 and 2015 for the whole study area, as well as for each block and line transect. For transects, we included all 1-ha squares on either side of the transect line, because $97 \%$ of grouse observed were located within $100 \mathrm{~m}$ of the transect. An index of heather management intensity was calculated as the proportion of 1-ha squares showing evidence of burning or cutting.

\section{Statistical analysis}

\section{Vegetation measurements and change over time}

Using linear regression, we compared heather cover in the blocks assessed from aerial surveys with estimates from ground surveys in 2015. To test how closely these two types of assessment corresponded with one another, we used the proportions of heather cover and heather presence from the ground surveys, each in turn, as the dependent variable and the matching proportion of heather cover from aerial surveys as the independent variable.

Changes in habitat between 2007, 2012, and 2015 (ground surveys) and between 2009 and 2015 (aerial surveys) were analyzed within a blocked ANOVA, with each habitat variable in turn (ground surveys: heather presence, heather cover, mean heather height, variation in heather height, heather management intensity, vegetation density; aerial surveys: heather cover, management intensity) as the response variable, year as treatment factor, and count area (blocks for ground surveys, blocks and transects for aerial surveys) as blocking factor. All proportions were logit-transformed before analysis. We also tested for collinearity between habitat variables using Pearson's correlation, including only noncorrelated variables $(|\mathrm{r}|<0.35, \mathrm{p}>0.05)$ in further analysis (heather cover, heather management intensity, and vegetation density).

\section{Spatial relationships between grouse demography and habitat}

To analyze the relationship between habitat measured from ground surveys and grouse demographic measures, we calculated mean grouse densities, productivity, and summer survival within each block from the two grouse survey years closest in time to each vegetation survey (i.e., 2008/2009, 2012/2013, and 2015/2016). Using two-year means helped to reduce the effect of small numbers of grouse in some blocks. Apparent winter survival was measured during the winter between these years. Data were analyzed using General Linear Mixed Models (GLMMs), with log-transformed grouse densities and productivity, each in turn, as the response variable. Year was included as a fixed factor, heather cover, heather management intensity, and vegetation density as covariates, and count block as a random factor. To account for variation in accuracy of count-derived estimates, we calculated the variances associated with the value of each response variable based on the confidence intervals of the distance sampling estimates and Taylor series linearization (Seber 1982), then weighted the analysis by the reciprocal of the variances. Initial models included interactions between year and each habitat variable, which were dropped if not significant. The analysis of survival rates was similar, except that because grouse survival has previously been shown to be density dependent (Thirgood et al. 2000b), we used the log-transformed density of adult grouse in July (apparent summer survival) or in spring (apparent winter survival), respectively, as the response variable and included the corresponding log-transformed density from the previous count as an additional covariate in the model (the corresponding regression coefficient then represents $1+\phi$, where $\phi$ is the slope of the density-dependent relationship). An equivalent analysis based on aerial surveys used grouse data in 2008/2009 and 2015/2016 from both the blocks and the transects, including year as a fixed factor, heather cover, and heather management intensity as covariates, and count area as a random factor.

To study the importance of pioneer regenerating heather (Miller et al. 1966), we also repeated all analyses for ground surveys using heather presence instead of heather cover. Because this analysis gave similar results, it is not considered further.

\section{Habitat influences on survival of radio-tagged grouse}

To test whether true grouse survival was related to heather cover, heather management intensity, or vegetation height in their seasonal home range, we used GLMMs. Survival was included as a binary response variable using Bernoulli errors and a logistic link function, and individual grouse identity as a random factor (as individual surviving grouse could contribute to survival estimation over successive seasons). Because of collinearity between habitat variables, the analysis was conducted as a series of univariate models using each habitat variable, year, season (summer/winter) and their respective interactions as explanatory variables. The habitat*year and habitat*season interactions were dropped from the model if not significant. 
We also tested if radio-tagged grouse moved into areas with higher heather cover by comparing heather cover in individual home ranges between two consecutive seasons. The logit-transformed proportion of heather was included as response variable in a GLMM with season as two-level factor (season $\mathrm{x}$ and season $\mathrm{x}+1$ ) and individual grouse identity as random factor (as individual grouse surviving for more than two consecutive seasons could contribute more than one season-pair).

\section{Temporal relationships between grouse demography and habitat}

To test whether changes in grouse densities, productivity, or survival within the blocks were associated with temporal changes in heather cover between 2007 and 2015, we calculated all changes between these survey periods as log-ratios, using the value from the latest survey period as numerator and the value from the first survey period as denominator. To allow the inclusion of zero values $(10 \%$ of prebreeding densities and $3 \%$ of postbreeding densities were zero), we added 0.5 to the total number of grouse counted in each area. The change in each grouse variable was included as response variable in a General Linear Model, weighted by the reciprocal of the variances of the response values, using the change in heather cover as explanatory variable.

We also conducted an equivalent analysis using aerial surveys and grouse data from both blocks and transects (2009-2015). For the calculation of changes in heather cover ( $2 \%$ zero values) we added 0.5 to one 1-ha plot in each count area.

\section{Relative importance of grazing versus management for grouse}

Management for grouse (predator control, burning/cutting heather, and provision of medicated grit) started in 2008 and was conducted until spring 2016, although medicated grit was withdrawn in 2014. Large-scale reductions in sheep grazing for the purpose of heather restoration did not occur until spring 2011, giving periods of combined and separate management of grouse and sheep. To help disentangle the relative effects of management of grouse and sheep on grouse demographic responses, we extended our grouse dataset to include the period without management for grouse and before sheep reduction in the eight years prior to the start of this study (i.e., 2000-2007), and two breeding seasons after management for grouse ceased and sheep had been reduced (2016-2017). We analyzed annual rates of change in prebreeding grouse density and productivity between 2000 and 2017, based on numbers of grouse counted within the blocks, using GLMMs. Years were categorized according to presence (2008-2015) or absence (2000-2007 and 2016-2017) of management for grouse (grouse management), and grazing intensity was measured as the number of sheep ha ${ }^{-1}$ in each block and year (range: 0-1.02). To test whether the annual rate of change in prebreeding grouse density varied in relation to grouse management and grazing intensity, we used prebreeding density (log-transformed) as response variable, grouse management, grazing intensity, and year (as continuous variable), and their interactions as fixed explanatory variables, and block as a random effect. The coefficients from the model were then used to calculate the slope of the relationship with year in relation to presence or absence of grouse management and three illustrative values of grazing intensity $\left(\right.$ none $=0$, moderate $=0.5$, high $=1$ sheep ha ${ }^{-1}$ ); the slope was back-transformed $\left(100 *\left[\mathrm{e}^{\mathrm{x}}-1\right]\right)$ to give a $\%$ change per annum. We examined the effects of grouse management and grazing on grouse productivity in a second model, where we used the young:adult ratio derived from the postbreeding counts as response variable (weighted by the number of young + adult grouse), grouse management, grazing intensity, and their interaction as fixed explanatory variables, and block as a random effect. Statistical analyses were conducted in GenStat 18.2 (VSN International 2015), and all values are given as means $\pm 1 \mathrm{SE}$ unless stated otherwise.

\section{RESULTS}

\section{Measuring heather cover}

Measures of heather cover assessed from aerial and ground surveys were positively correlated (Fig. 2), and measures from aerial surveys corresponded with measures of heather dominance (cover) in ground surveys. However, aerial surveys underestimated heather presence relative to ground surveys. This difference was greatest when the amount of heather was low and suggested that there could be heather present at up to $36 \pm 3 \%$ of sample points on a ground survey before heather cover was detected from the air. The indices for heather management intensity derived from ground and aerial surveys were not related $(\mathrm{r}=0.27, \mathrm{n}=10, \mathrm{p}=$ $0.45)$.

Fig. 2. Relationship between $\%$ heather (Calluna vulgaris) cover assessed from aerial surveys and $\%$ heather presence (open symbols; slope: $0.754 \pm 0.059, \mathrm{~F}_{1,8}=163.91, \mathrm{p}<0.001$; intercept: $0.364 \pm 0.029, \mathrm{p}<0.001$ ) and heather cover (filled symbols; slope: $0.915 \pm 0.145, \mathrm{~F}_{1.8}=39.97, \mathrm{p}<0.001$; intercept: $0.126 \pm 0.071, \mathrm{p}=0.116$ ) assessed during ground surveys in $2015(\mathrm{~N}=10$ count areas).

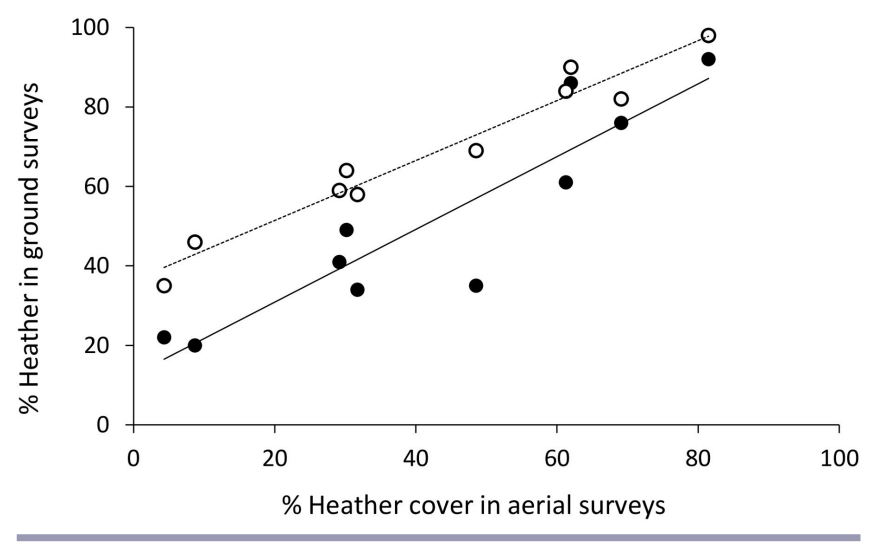

\section{Changes in heather cover}

The ground surveys in the blocks showed small and nonsignificant increases in heather presence and cover from 2007 to 2012 (Table $1)$, but between 2012 and 2015, heather presence $\left(\mathrm{F}_{1,8}=28.49, \mathrm{p}\right.$ $<0.001)$ and heather cover $\left(\mathrm{F}_{1.8}=8.83, \mathrm{p}=0.016\right)$ both increased by a third. Neither heather height nor management intensity changed, but variance in height decreased, while vegetation density increased.

Assessment of aerial photographs showed a $10 \%$ increase in the total area with heather and a $30 \%$ increase in the area with heatherdominated vegetation (i.e. heather cover $>50 \%$ ) over the study 
Table 1. Changes in heather (Calluna vulgaris) variables (mean $\pm \mathrm{se}$ ) measured during ground surveys within the Red Grouse (Lagopus lagopus scotica) blocks ( $\mathrm{N}=10)$.

\begin{tabular}{lcccc}
\hline \hline & 2007 & 2012 & 2015 & ANOVA \\
\hline Heather presence (\%) & $48 \pm 8$ & $52 \pm 8$ & $69 \pm 6$ & $\mathrm{~F}_{2,18}=6.84, \mathrm{p}=0.006$ \\
Heather cover (\%) & $38 \pm 6$ & $39 \pm 7$ & $52 \pm 8$ & $\mathrm{~F}_{2,18}=2.12, \mathrm{p}=0.149$ \\
Heather height (cm) & $34.1 \pm 1.2$ & $33.6 \pm 1.9$ & $32.9 \pm 1.6$ & $\mathrm{~F}_{2,17}=0.34, \mathrm{p}=0.714$ \\
Var. in height & $13.1 \pm 1.3$ & $10.4 \pm 1.0$ & $10.3 \pm 0.8$ & $\mathrm{~F}_{2,17}=4.61, \mathrm{p}=0.025$ \\
Vegetation density (\%) & $27 \pm 4$ & $63 \pm 5$ & $76 \pm 4$ & $\mathrm{~F}_{2,18}=29.68, \mathrm{p}<0.001$ \\
Management intensity (\%) & $5 \pm 2$ & $3 \pm 2$ & $1 \pm 0.3$ & $\mathrm{~F}_{2,18}=2.24, \mathrm{p}=0.135$ \\
\end{tabular}

Table 2. Changes in heather (Calluna vulgaris) variables measured during aerial surveys. (A) Area $\left(\mathrm{km}^{2}\right)$ with heather (1-ha squares with $\geq 1 \%$ heather cover) and heather-dominant vegetation (1-ha squares with $>50 \%$ heather cover) in study area and buffer zone; the respective percentage cover is given in brackets. (B) Mean ( \pm se) heather cover and heather management intensity (burning or cutting) in the Red Grouse (Lagopus lagopus scotica) count areas.

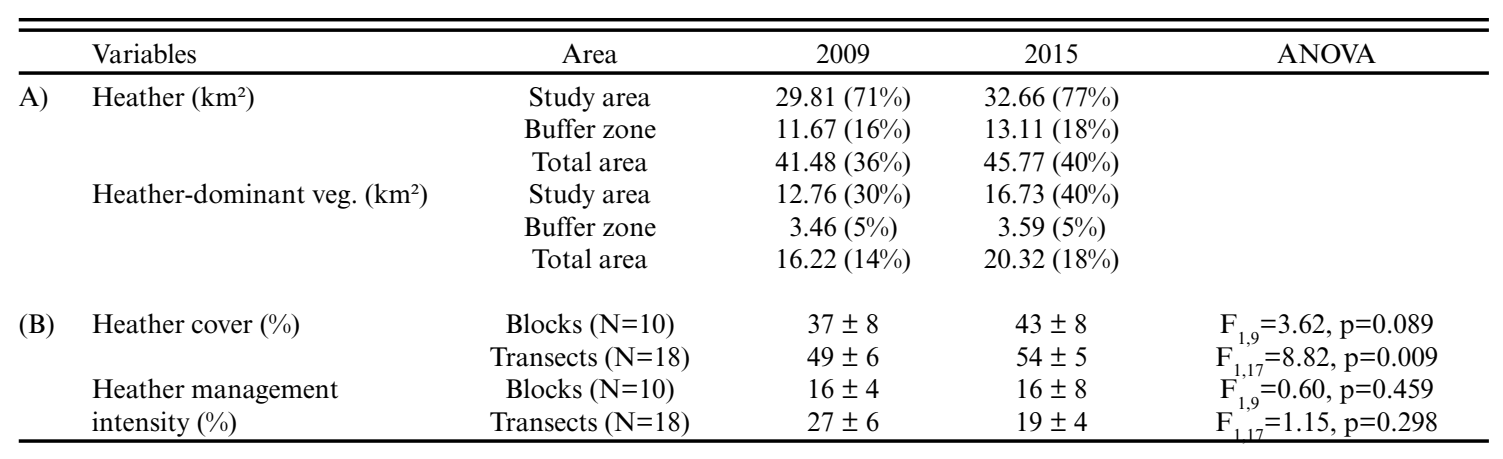

area between 2009 and 2015 (Table 2). Heather cover increased by $16 \%$ within blocks and by $10 \%$ along transects, although only the latter was significant. Approximately $20-25 \%$ of the heather showed signs of heather management; of that, $18 \%$ was burning, $45-55 \%$ cutting, and $27-37 \%$ a mix of both, for example where burns were bordered by cuts. The heather management index did not change between 2009 and 2015 in either the blocks or along the transects.

\section{Spatial relationships between grouse demographic rates and habitat}

We found no effect of survey year on the relationships between grouse demographic rates and habitat variables (no significant interactions with year). Prebreeding grouse densities were positively related to heather cover assessed by both ground and aerial surveys (Table 3, see also Figure A2.1 in Appendix 2), whereas postbreeding grouse densities were related to heather cover only for aerial surveys. Grouse productivity was not related to heather cover in either survey, and no significant relationships were found with heather management intensity or vegetation density.

Apparent survival of grouse was negatively related to the density of grouse at the start of both summer and winter season (Table 3). However, neither apparent summer survival of adults nor apparent winter survival were found to be significantly related to heather cover, although apparent winter survival tended to be positively related to management intensity assessed from ground surveys. Survival of radio-tagged grouse over summer or winter was unrelated to heather cover $\left(0.009 \pm 0.015, \chi^{2}{ }_{1}=0.36, \mathrm{p}=\right.$ $0.552)$, heather management intensity $\left(0.022 \pm 0.047, \chi^{2}=0.22\right.$, $\mathrm{p}=0.641)$, and vegetation height $\left(0.011 \pm 0.043, \chi_{1}{ }_{1}=0.07, \mathrm{p}=\right.$ 0.799 ) within their seasonal home range, despite large variation in heather cover (range 5-67\%). Radio-tagged grouse also did not move their home ranges into areas with higher heather cover between consecutive seasons $(\mathrm{N}=101$ season-pairs; season: $\left.-0.002 \pm 0.075, \chi_{1}^{2}=0.00, p=0.984\right)$.

\section{Temporal relationships between grouse demographic rates and habitat}

Temporal changes in prebreeding grouse densities tended to be positively related to temporal changes in heather cover during the full period covered by ground surveys (Table 4), unlike changes in postbreeding densities, productivity, or survival. Separating the two periods assessed by ground surveys, changes in prebreeding grouse densities were positively related to changes in heather cover between 2007 and $2012\left(1.06 \pm 0.18, \mathrm{~F}_{1,8}=33.95, \mathrm{p}<0.001\right)$ but not between 2012 and $2015\left(-1.50 \pm 1.14, \mathrm{~F}_{1,8}=1.74, \mathrm{p}=0.224\right)$. When changes in heather cover were assessed from aerial surveys, we found that temporal changes in prebreeding grouse densities and productivity were positively related to temporal changes in heather cover (Table 4).

\section{Relative importance of grazing versus management for grouse}

When testing the effect of management for grouse, grazing intensity and year on prebreeding grouse density, we found a 
Table 3. Relationship between Red Grouse (Lagopus lagopus scotica) density and demographic rates (derived from counts) and habitat variables assessed in the same period during ground surveys within the blocks in 2007, 2012, and 2015, or from aerial surveys within the blocks and along transects in 2009 and 2015. All habitat variables were included as proportions. Values are estimates of slope \pm SE. Sample sizes for productivity are reduced owing to the absence of grouse in July in one block in the first survey period. Nonsignificant year*habitat interactions were removed from the models.

\begin{tabular}{|c|c|c|c|c|c|}
\hline Variables & Prebreeding density & $\begin{array}{c}\text { Postbreeding } \\
\text { density }\end{array}$ & Productivity & $\begin{array}{l}\text { Apparent summer } \\
\text { survival }\end{array}$ & Apparent winter survival \\
\hline \multicolumn{6}{|l|}{ Ground surveys } \\
\hline $\mathrm{N}$ & 30 & 30 & 29 & 30 & 30 \\
\hline $\ln$ (Density previous & & & & $0.49 \pm 0.09^{\dagger}$ & $0.84 \pm 0.18^{\dagger}$ \\
\hline count) & & & & $\mathrm{X}^{2}=27.94, \mathrm{p}<0.001$ & $\mathrm{X}^{2}{ }_{1}=22.68, \mathrm{p}<0.001$ \\
\hline \multirow[t]{2}{*}{ Heather cover } & $1.99 \pm 0.78$ & $1.63 \pm 1.01$ & $-0.34 \pm 0.30$ & $0.26 \pm 0.41$ & $0.80 \pm 0.52$ \\
\hline & $\mathrm{X}_{1}{ }_{1}=6.43, \mathrm{p}=0.029$ & $\mathrm{X}_{1}{ }_{1}=2.63, \mathrm{p}=0.133$ & $\mathrm{X}_{1}^{2}=1.26, \mathrm{p}=0.311$ & $\mathrm{X}_{1}^{2}=0.41, \mathrm{p}=0.539$ & $\mathrm{X}_{1}{ }_{1}=2.34, \mathrm{p}=0.185$ \\
\hline \multirow[t]{2}{*}{ Management intensity } & $8.29 \pm 4.27$ & $5.22 \pm 4.49$ & $1.45 \pm 2.01$ & $-3.64 \pm 220$ & $7.27 \pm 3.39$ \\
\hline & $\mathrm{X}^{2}{ }_{1}=3.76, \mathrm{p}=0.065$ & $\mathrm{X}_{1}^{2}=1.35, \mathrm{p}=0.258$ & $\mathrm{X}_{1}^{2}=0.52, \mathrm{p}=0.483$ & $\mathrm{X}^{2}{ }_{1}=2.74, \mathrm{p}=0.121$ & $\mathrm{X}_{1}^{2}=4.60, \mathrm{p}=0.054$ \\
\hline \multirow[t]{2}{*}{ Vegetation density } & $-0.19 \pm 1.14$ & $0.62 \pm 1.03$ & $0.49 \pm 0.65$ & $0.40 \pm 0.71$ & $-0.79 \pm 1.00$ \\
\hline & $\mathrm{X}_{1}{ }_{1}=0.03, \mathrm{p}=0.871$ & $\mathrm{X}_{1}^{2}=0.36, \mathrm{p}=0.554$ & $\mathrm{X}_{1}^{2}=0.57, \mathrm{p}=0.459$ & $\mathrm{X}_{1}{ }_{1}=0.32, \mathrm{p}=0.576$ & $\mathrm{X}_{1}^{2}=0.62, \mathrm{p}=0.442$ \\
\hline \multicolumn{6}{|l|}{ Aerial surveys } \\
\hline & 56 & 56 & 55 & 56 & 56 \\
\hline \multirow{2}{*}{$\begin{array}{l}\ln (\text { Density previous } \\
\text { count) }\end{array}$} & & & & $0.54 \pm 0.11^{\dagger}$ & $0.36 \pm 0.12^{\dagger}$ \\
\hline & & & & $\mathrm{X}_{1}^{2}=24.03, \mathrm{p}<0.001$ & $\mathrm{X}_{1}^{2}=8.74, \mathrm{p}=0.005$ \\
\hline \multirow[t]{2}{*}{ Heather cover } & $1.89 \pm 0.46$ & $1.64 \pm 0.57$ & $-0.30 \pm 0.45$ & $0.70 \pm 0.42$ & $1.06 \pm 0.60$ \\
\hline & $\mathrm{X}_{1}^{2}=14.84, \mathrm{p}<0.001$ & $\mathrm{X}_{1}^{2}=8.27, \mathrm{p}=0.008$ & $\mathrm{X}_{1}^{2}=0.45, \mathrm{p}=0.508$ & $\mathrm{X}_{1}{ }_{1}=2.83, \mathrm{p}=0.102$ & $\mathrm{X}_{1}{ }_{1}=3.09, \mathrm{p}=0.088$ \\
\hline \multirow[t]{2}{*}{ Management intensity } & $-0.69 \pm 0.48$ & $-0.14 \pm 0.62$ & $0.52 \pm 0.41$ & $-0.22 \pm 0.40$ & $-0.63 \pm 0.55$ \\
\hline & $\mathrm{X}_{1}{ }_{1}=2.09, \mathrm{p}=0.159$ & $\mathrm{X}^{2}{ }_{1}=0.05, \mathrm{p}=0.826$ & $\mathrm{X}^{2}{ }_{1}=1.57, \mathrm{p}=0.217$ & $\mathrm{X}_{1}{ }_{1}=0.30, \mathrm{p}=0.589$ & $\mathrm{X}^{2}{ }_{1}=1.32, \mathrm{p}=0.259$ \\
\hline
\end{tabular}

${ }^{\dagger}$ The slope of the density dependent relationship is obtained by subtracting 1 (see Methods).

Table 4. Regression analysis relating changes in $\%$ heather (Calluna vulgaris) cover obtained from ground and aerial surveys to changes in Red Grouse (Lagopus lagopus scotica) demography during the study period. All changes were calculated as log-ratios. Sample sizes for productivity and survival are reduced owing to the absence of grouse in some count areas during the first surveys.

\begin{tabular}{lcc}
\hline \hline Variables & Slope $\pm \mathrm{SE}$ & $\mathrm{F}, \mathrm{p}$ \\
\hline Ground surveys & & \\
Change in prebreeding density & $0.68 \pm 0.31$ & $\mathrm{~F}_{1,8}=4.97, \mathrm{p}=0.056$ \\
Change in postbreeding density & $0.49 \pm 0.80$ & $\mathrm{~F}_{1,8}=0.37, \mathrm{p}=0.559$ \\
Change in productivity & $0.42 \pm 0.26$ & $\mathrm{~F}_{1,7}=2.58, \mathrm{p}=0.152$ \\
Change in summer survival & $0.26 \pm 1.41$ & $\mathrm{~F}_{1,6}=0.03, \mathrm{p}=0.861$ \\
Change in winter survival & $-1.80 \pm 1.28$ & $\mathrm{~F}_{1,6}=1.97, \mathrm{p}=0.210$ \\
& & \\
Aerial surveys & & \\
Change in prebreeding density & $0.23 \pm 0.10$ & $\mathrm{~F}_{1,26}=5.12, \mathrm{p}=0.032$ \\
Change in postbreeding density & $0.22 \pm 0.19$ & $\mathrm{~F}_{1,26}=1.28, \mathrm{p}=0.267$ \\
Change in productivity & $0.16 \pm 0.08$ & $\mathrm{~F}_{1,25}=4.26, \mathrm{p}=0.050$ \\
Change in summer survival & $-1.21 \pm 0.70$ & $\mathrm{~F}_{1,23}=2.98, \mathrm{p}=0.098$ \\
Change in winter survival & $1.69 \pm 0.96$ & $\mathrm{~F}_{120}=3.08, \mathrm{p}=0.095$ \\
\hline
\end{tabular}

significant three-way interaction between all three explanatory variables $\left(\chi_{1}^{2}=4.06, p=0.046\right)$. The slope of year, and hence $\%$ change in grouse prebreeding density, varied in relation to management for grouse and grazing according to the equation:

Slope $=0.034+0.160 *$ management $+0.025 *$ grazing $-0.180 *$ management $*$ grazing

To interpret this equation, we used it to calculate $\%$ change in grouse prebreeding density in relation to grouse management and grazing intensity. In the absence of management for grouse, any effect of grazing intensity on the $\%$ change in grouse prebreeding density was minimal and within the estimation errors (no grazing: $3.5 \pm 1.4 \%$, moderate: $4.8 \pm 2.6 \%$, high: $6.1 \pm 4.2 \%)$. With management for grouse, the $\%$ change decreased with grazing intensity (no grazing: $21.4 \pm 4.9 \%$, moderate: $12.4 \pm 7.7 \%$, high: $4.0 \pm 11.2 \%)$.

For productivity, we found no interaction between management for grouse and grazing intensity. Productivity was 37\% higher in years with management for grouse (unmanaged: $1.1 \pm 0.1$, managed: $1.5 \pm 0.1$; effect size $0.47 \pm 0.18 ; \chi^{2}{ }_{1}=6.83, p=0.010$ ), but not associated with grazing intensity (slope $-0.24 \pm 0.19 ; \chi^{2}$ $\left.{ }_{1}=1.55, \mathrm{p}=0.215\right)$.

\section{DISCUSSION}

The reduction in sheep grazing pressure was associated with increased heather cover during the study period, although the recorded extent of recovery differed between ground and aerial surveys. Although measures of heather cover from aerial surveys corresponded to measures of heather dominance in ground surveys, the latter detected up to $36 \%$ higher heather presence and probably included young plants in the pioneer stage that could not be detected from aerial images but would represent a significant food source for grouse. However, ground surveys were restricted to sampling within grouse count blocks, while aerial surveys, although underestimating heather when in a mosaic with other vegetation, could be used to assess heather cover not only within the whole study area, but also its wider surrounding buffer zone. The area of heather-dominated vegetation in the study area (30-40\%; Table 2) was lower than in 1988 (approximately 56\%; Thirgood et al. 2000a). However, the increase in heather cover 
between 2007 and 2015 within the grouse count blocks restored heather levels to those recorded in 1997 (Baines et al. 2008), when driven grouse shooting ceased at Langholm Moor after an increase in raptor predation reduced the number of grouse available for shooting in the autumn (Thirgood et al. 2000a). The large variation in heather cover in the count blocks and transects, ranging from $0-92 \%$ in both ground and aerial surveys, aided our investigation of the relationship between heather cover and grouse densities and demographic rates.

As predicted, prebreeding, and for aerial surveys also postbreeding, densities of grouse were higher in areas with more heather. However, neither productivity nor apparent survival rates were related to heather cover. In accordance with a previous study at the same site (Thirgood et al. 2000b), we found that apparent summer and winter survival were negatively related to grouse density. Survival of radio-tagged individuals also showed no relationship with any habitat measure, and there was no evidence that adult grouse moved their home ranges into areas with increasing heather cover. Over time, change in heather cover was positively related to change in prebreeding grouse densities as predicted, however, there was no association with change in postbreeding densities or apparent survival rates. Temporal changes in productivity were associated with changes in heather cover assessed from aerial surveys, but not from ground surveys.

Unlike Robertson et al. (2017a), who studied 34 driven grouse moors in northern England, we found no significant relationships between grouse productivity, postbreeding density, and heather management intensity, i.e., burning and cutting. However, the average intensity of heather management at Langholm was fivefold lower than that described by Robertson et al. (2017a). This suggests that either the degree of heather management was too low to deliver the benefits to grouse described by Palmer and Bacon (2001), or other factors, such as predation, may have been more important in determining grouse measures (Fletcher et al. 2013). However, the heather management index derived from ground surveys was not related to that from aerial surveys, and it is possible that evidence of burns and cuts may be less conspicuous from the ground than the air. The relatively high heather management index for ground surveys in 2007 may be attributable to higher levels of sheep grazing, which would restrict postburning heather recovery, rendering evidence of burning discernible for longer.

Our finding that grouse demographic rates were not associated with habitat measures concurs with Campbell et al. (2002), who found that despite Red Grouse nesting in taller, more dense vegetation, this was not associated with higher nesting success. Similarly, Thirgood et al. (2002) found no influence of habitat on Red Grouse mortality rates. They concluded that the direct effects of habitat on the susceptibility of grouse to predation were limited on moorland managed for grouse shooting, where generalist predators, such as corvids and red foxes, were fewer following their routine control. However, there is also evidence that the hunting success of some moorland predators, such as Hen Harrier, is not affected by heather structure (Thirgood et al. 2002). In contrast, studies of lowland Galliformes have found strong positive effects of vegetation height and density on nesting success (Rands 1988, McKee et al. 1998, Taylor et al. 1999). The observed lack of productivity or survival response in our study area to heather management by grouse, coupled with the low likelihood of immigration from other moors, means that an expansion of the overall area of heather is unlikely to increase overall grouse density unless combined with control of generalist predators. Predation was the most important factor determining survival of adults and chicks, which contributed most to annual population change (Ludwig et al. 2018b). However, increased abundance of potential predators such as Hen Harriers, foxes, and crows during the later years of this study (Ludwig et al. 2017) may have masked any potential variation in productivity or survival in response to increased heather cover.

At Langholm, grouse responded quickly to the resumption of grouse-moor management in 2008 with increased productivity (Ludwig et al. 2017). This resulted in more juveniles present, which most likely settled in areas with more heather (for similar results, see Thirgood et al. 2002). This may have driven the temporal association between heather cover and grouse densities in the earlier years (2008-2012). Reductions in sheep grazing did not occur until 2011 and the response of heather was likely associated with a further time-lag. However, during the later years of this study, when heather recovery accelerated, we found that grouse densities did not respond to increases in heather cover. By considering the context provided by the extended data set (20002017), the highest proportional changes in prebreeding grouse densities were associated with the presence of management for grouse, i.e., predator and parasite control and heather burning/ cutting, and no or moderate levels of sheep grazing. However, there was no effect of grazing intensity on changes in grouse densities in the absence of management for grouse. Grouse productivity was also higher in years with management for grouse but was not related to grazing intensity. This is consistent with other studies suggesting that predation has a stronger effect than habitat quality on population growth of Red Grouse (e.g., Thirgood et al. 2002, Fletcher et al. 2010), and with the positive effect of predator control on other ground-nesting birds (PearceHiggins and Yalden 2003, Fletcher et al. 2010, Douglas et al. 2014, Buchanan et al. 2017, Ludwig et al. 2017).

In some UK regions, the number of grouse shot has increased against a backdrop of declines in heather cover between 1950 and 2010 (Robertson et al. 2017b). Furthermore, other grouse moors achieve much higher postbreeding densities than Langholm even when accounting for between-moor differences in heather cover. For example, postbreeding densities on grouse moors in northern England averaged 500 birds $\mathrm{km}^{-2}$ in 2010 (Robertson et al. 2017a; raw counts converted into distance sampling estimates following Warren and Baines 2011), while those at Langholm peaked at 123 birds $\mathrm{km}^{-2}$ in 2013. In contrast to Langholm, many of these moors, especially in the Pennine range and North York Moors, are part of a wider contiguous open moorland landscape managed for grouse, where predators are fewer (Tapper 1992, Harris and Yalden 2008, Fletcher et al. 2010, Balmer et al. 2013, Douglas et al. 2014), and habitat, predator, and disease management in the interests of grouse is increasingly intensive (Douglas et al. 2015, Robertson et al. 2017b). This suggests that high grouse densities may be achievable even at low levels of heather cover if predator and disease management is sufficiently intensive (e.g., Robertson et al. 2017b). Nevertheless, the positive relationship between grouse prebreeding density and heather cover, which has also been found in other studies (Miller et al. 1966, Pearce-Higgins and 
Grant 2006), suggests that, at sites such as Langholm Moor that have experienced decades of heather loss, heather restoration may be able to increase grouse carrying capacity in the long term. At Langholm, there are potential but as yet unrealized benefits from increased contiguity of heather cover and restoration of heather at lower elevations in the buffer zone, from which both heather and grouse were almost completely lost (Redpath and Thirgood 1997). However, realizing this potential first requires improving grouse demographic rates.

Where habitat loss has contributed to declines in avian populations, it is often assumed that the restoration of habitat will lead to population recovery. However, our results are consistent with other studies suggesting that habitat restoration alone may be insufficient to increase populations that have become constrained by demographic factors, e.g., high mortality associated with predation (Schrott et al. 2005, Fletcher et al. 2006). Detailed long-term studies with temporal and spatial variation in management of habitat and predation may help to identify the relative importance of the different factors, as well as highlighting how loss of habitat may interact with predation to cause population declines (e.g., Evans 2004).

\section{Responses to this article can be read online at:} http://www.ace-eco.org/issues/responses.php/1306

\section{Acknowledgments:}

This study was conducted as part of the Langholm Moor Demonstration Project, funded by the Game and Wildlife Conservation Trust, Scottish Natural Heritage, Buccleuch Estates, Royal Society for the Protection of Birds, and Natural England. We are grateful to $M$. Becker, T. Chamberlain, K. Fingland, P. Golder, H. Greetham, K. Hazelwood, R. Jayasuriya, P. Keane, M. Layton, A. McCluskie, A. McWilliam, T. Pringle, E. Rooney, and E. Trevail for assistance with fieldwork. D. Thompson, M. Wilson, and two anonymous reviewers provided helpful comments on earlier drafts of this manuscript.

\section{LITERATURE CITED}

Amar, A., M. Grant, G. Buchanan, I. Sim, J. Wilson, J. W. PearceHiggins, and S. Redpath. 2011. Exploring the relationships between wader declines and current land-use in the British uplands. Bird Study 58:13-26. http://dx.doi.org/10.1080/00063657.2010 .513412

Andrén, H. 1994. Effects of habitat fragmentation on birds and mammals in landscapes with different proportions of suitable habitat: a review. Oikos 71:355-366. http://dx.doi.org/10.2307/3545823

Baines, D. 1996. The implications of grazing and predator management on the habitats and breeding success of Black Grouse Tetrao tetrix. Journal of Applied Ecology 33:54-62. http:// dx.doi.org/10.2307/2405015

Baines, D., S. M. Redpath, M. Richardson, and S. Thirgood. 2008. The direct and indirect effects of predation by Hen Harriers Circus cyraneus on trends in breeding birds on a Scottish grouse moor. Ibis 150:27-36. http://dx.doi.org/10.1111/j.1474-919X.2008.00848. $\mathrm{x}$
Balmer, D., S. Gillings, B. Caffrey, B. Swann, I. Downie, and R. Fuller. 2013. Bird Atlas 2007-11. The breeding and wintering birds of Britain and Ireland. BTO Books, Thetford, UK.

Buchanan, G. M., J. W. Pearce-Higgins, D. J. T. Douglas, and M. C. Grant. 2017. Quantifying the importance of multi-scale management and environmental variables on moorland bird abundance. Ibis 159:744-756. http://dx.doi.org/10.1111/ibi.12488

Buckland, S. T., D. R. Anderson, K. P. Burnham, J. L. Laake, D. L. Borchers, and L. Thomas. 2001. Introduction to distance sampling. Oxford University Press, Oxford, UK.

Bro, E., P. Mayot, E. Corda, and F. Reitz. 2004. Impact of habitat management on Grey Partridge populations: assessing wildlife cover using a multisite BACI experiment. Journal of Applied Ecology 41:846-857. http://dx.doi.org/10.1111/j.0021-8901.2004.00939. $\mathrm{x}$

Brooks, T. M., R. A. Mittermeier, C. G. Mittermeier, G. A. B. Da Fonseca, A. B. Rylands, W. R. Konstant, P. Flick, J. Pilgrim, S. Oldfield, G. Magin, and C. Hilton-Taylor. 2002. Habitat loss and extinction in the hotspots of biodiversity. Conservation Biology 16:909-923. http://dx.doi.org/10.1046/j.1523-1739.2002.00530.x

Calladine, J., D. Baines, and P. Warren. 2002. Effects of reduced grazing on population density and breeding success of Black Grouse in northern England. Journal of Applied Ecology 39:772-780. http://dx.doi.org/10.1046/j.1365-2664.2002.00753.x

Campbell, S., A. Smith, S. Redpath, and S. Thirgood. 2002. Nest site characteristics and nest success in Red Grouse Lagopus lagopus scoticus. Wildlife Biology 8:169-174. http://dx.doi. org/10.2981/wlb.2002.030

Cattadori, I. M., D. T. Haydon, S. J. Thirgood, and P. J. Hudson. 2003. Are indirect measures of abundance a useful index of population density? The case of Red Grouse harvesting. Oikos 100:439-446. http://dx.doi.org/10.1034/j.1600-0706.2003.12072. $\mathrm{x}$

Douglas, D. J. T., P. E. Bellamy, L. S. Stephen, J. W. PearceHiggins, J. D. Wilson, and M. C. Grant. 2014. Upland land use predicts population decline in a globally near-threatened wader. Journal of Applied Ecology 51:194-203. http://dx.doi. org/10.1111/1365-2664.12167

Douglas, D. J. T., G. M. Buchanan, P. Thompson, A. Amar, D. A. Fielding, S. M. Redpath, and J. D. Wilson. 2015. Vegetation burning for game management in the UK uplands is increasing and overlaps spatially with soil carbon and protected areas. Biological Conservation 191:243-250. http://dx.doi.org/10.1016/j. biocon.2015.06.014

Evans, K. L. 2004. The potential for interactions between predation and habitat change to cause population declines of farmland birds. Ibis 146:1-13. http://dx.doi.org/10.1111/ j.1474-919X.2004.00231.x

Fletcher, K., N. J. Aebischer, D. Baines, R. Foster, and A. N. Hoodless. 2010. Changes in breeding success and abundance of ground-nesting moorland birds in relation to the experimental deployment of legal predator control. Journal of Applied Ecology 47:263-272. http://dx.doi.org/10.1111/j.1365-2664.2010.01793.x

Fletcher, K., A. N. Hoodless, and D. Baines. 2013. Impacts of predator abundance on Red Grouse Lagopus lagopus scotica 
during a period of experimental predator control. Wildlife Biology 19:248-256. http://dx.doi.org/10.2981/12-009

Fletcher, R. J., Jr, R. R. Koford, and D. A. Seaman. 2006. Critical demographic parameters for declining songbirds breeding in restored grasslands. Journal of Wildlife Management 70:145-157. http://dx.doi.org/10.2193/0022-541X(2006)70[145:CDPFDS]2.0. $\mathrm{CO} ; 2$

Fuller, R. J., and S. J. Gough. 1999. Changes in sheep numbers in Britain: implications for bird populations. Biological Conservation 91:73-89. http://dx.doi.org/10.1016/S0006-3207(99) 00039-7

Harris, S., and D. Yalden. 2008. Mammals of the British Isles: Handbook. Mammal Society, London, UK.

Hudson P. J., A. P. Dobson, and D. Newborn. 1998. Prevention of population cycles by parasite removal. Science 282:2256-2258. http://dx.doi.org/10.1126/science.282.5397.2256

Hudson, P. J., and D. Newborn. 1995. Red grouse and moorland management. Game Conservancy Trust, Fordingbridge, UK.

Kenward, R. E., N. M. Casey, S. S. Walls, and A. B. South. 2014. Ranges 9: For the analysis of tracking and location data. Online manual. Anatrack Ltd., Wareham, UK.

Ludwig, S. C., N. J. Aebischer, D. Bubb, S. Roos, and D. Baines. 2018b. Survival of chicks and adults explains variation in population growth in a recovering Red Grouse Lagopus lagopus scotica population. Wildlife Biology 2018:wlb.00430. http://dx. doi.org/10.2981/wlb.00430

Ludwig, S. C., A. McCluskie, P. Keane, C. Barlow, R. M. Francksen, D. Bubb, S. Roos, N. J. Aebischer, and D. Baines. 2018a. Diversionary feeding and nestling diet of Hen Harriers Circus cyaneus. Bird Study. http://dx.doi.org/10.1080/00063657.2018.1519524

Ludwig, S. C., S. Roos, D. Bubb, and D. Baines. 2017. Long-term trends in abundance and breeding success of Red Grouse and Hen Harriers in relation to changing management of a Scottish grouse moor. Wildlife Biology wlb.00246. http://dx.doi.org/10.2981/ wlb.00246

McCallum, H. M., J. D. Wilson, M. G. O'Brien, D. Beaumont, R. Sheldon, and K. J. Park. 2018. Fodder crop management benefits Northern Lapwing (Vanellus vanellus) outside agrienvironment schemes. Agriculture, Ecosystems and Environment 265:470-475. http://dx.doi.org/10.1016/j.agee.2018.06.027

McKee, G., M. R. Ryan, and L. M. Mechlin. 1998. Predicting Greater Prairie-Chicken nest success from vegetation and landscape characteristics. Journal of Wildlife Management 62:314-321. http://dx.doi.org/10.2307/3802294

Miller, G. R., D. Jenkins, and A. Watson. 1966. Heather performance and Red Grouse populations. I. Visual estimates of heather performance. Journal of Applied Ecology 3:313-326. http://dx.doi.org/10.2307/2401255

Morton, D., C. Rowland, C. Wood, L. Meek, C. Marston, G. Smith, R. Wadsworth, and I. C. Simpson. 2011. Final report for LCM2007 - the new UK Land Cover Map. CS Technical Report No. 11/07. NERC/Centre for Ecology and Hydrology, UK.
Newborn, D., and R. Foster. 2002. Control of parasite burdens in wild Red Grouse Lagopus lagopus scoticus through the indirect application of anthelmintics. Journal of Applied Ecology 39:909-914. http://dx.doi.org/10.1046/j.1365-2664.2002.00771.x

Ortega-Álvarez, R., and R. Lindig-Cisneros. 2012. Feathering the scene: the effects of ecological restoration on birds and the role birds play in evaluating restoration outcomes. Ecological Restoration 30:116-127. http://dx.doi.org/10.3368/er.30.2.116

Palmer, S. C. F., and P. J. Bacon. 2001. The utilization of heather moorland by territorial Red Grouse Lagopus lagopus scoticus. Ibis 143:222-232. http://dx.doi.org/10.1111/j.1474-919X.2001.tb04478.

\section{$\mathrm{X}$}

Pearce-Higgins, J. W., and M. C. Grant. 2006. Relationships between bird abundance and the composition and structure of moorland vegetation. Bird Study 53:112-125. http://dx.doi. org/10.1080/00063650609461424

Pearce-Higgins, J. W., and D. W. Yalden. 2003. Golden Plover Pluvialis apricaria breeding success on a moor managed for shooting Red Grouse Lagopus lagopus. Bird Study 50:170-177. http://dx.doi.org/10.1080/00063650309461309

Rands, M. R. W. 1988. The effect of nest site selection on nest predation in Grey Partridge Perdix perdix and Red-legged Partridge Alectoris rufa. Ornis Scandinavica 19:35-40. http://dx. doi.org/10.2307/3676525

Redpath, S. M., and S. J. Thirgood. 1997. Birds of prey and red grouse. Stationery Office, London, UK.

Redpath, S. M., and S. J. Thirgood. 1999. Numerical and functional responses in generalist predators: Hen Harriers and Peregrines on Scottish grouse moors. Journal of Animal Ecology 68:879-892. http://dx.doi.org/10.1046/j.1365-2656.1999.00340.x

Redpath, S. M., S. J. Thirgood, and F. M. Leckie. 2001. Does supplementary feeding reduce predation of Red Grouse by Hen Harriers? Journal of Applied Ecology 38:1157-1168. http://dx.doi. org/10.1046/j.0021-8901.2001.00683.x

Robertson, G. S., N. J. Aebischer, and D. Baines. 2017b. Using harvesting data to examine temporal and regional variation in Red Grouse abundance in the British uplands. Wildlife Biology 2017:wlb.00276.

Robertson, G. S., D. Newborn, M. Richardson, and D. Baines. 2017a. Does rotational heather burning increase Red Grouse abundance and breeding success on moors in northern England? Wildlife Biology 2017:wlb.00227.

Robertson, P. A., K. J. Park, and A. F. Barton. 2001. Loss of heather Calluna vulgaris moorland in the Scottish uplands: the role of Red Grouse Lagopus lagopus scoticus management. Wildlife Biology 7:11-16. http://dx.doi.org/10.2981/wlb.2001.004

Roos, S., J. Smart, D. W. Gibbons, and J. D. Wilson. 2018. A review of predation as a limiting factor for bird populations in mesopredator-rich landscapes: a case study of the UK. Biological Reviews 93:1915-1937. http://dx.doi.org/10.1111/brv.12426

Schmiegelow, F. K. A., and M. Mönkkönen. 2002. Habitat loss and fragmentation in dynamic landscapes: avian perspectives from the boreal forest. Ecological Applications 12:375-389. 
Avian Conservation and Ecology 13(2): 14

Schrott, G. R., K. A. With, and A. W. King. 2005. Demographic limitations of the ability of habitat restoration to rescue declining populations. Conservation Biology 19:1181-1193. http://dx.doi. org/10.1111/j.1523-1739.2005.00205.X

Seber, G. A. F. 1982. The estimation of animal abundance and related parameters. Second edition. Charles Griffin, London, UK.

Sotherton, N., S. Tapper, and A. Smith. 2009. Hen Harriers and Red Grouse: economic aspects of Red Grouse shooting and the implications for moorland conservation. Journal of Applied Ecology 46:955-960. http://dx.doi.org/10.1111/j.1365-2664.2009.01688. $\mathrm{x}$

Tapper, S. C. 1992. Game heritage: an ecological review from shooting and gamekeeping records. Game Conservancy Ltd., Fordingbridge, UK

Taylor, J. S., K. E. Church, and D. H. Rusch. 1999. Microhabitat selection by nesting and brood-rearing Northern Bobwhite in Kansas. Journal of Wildlife Management 63:686-694. http://dx. doi.org/10.2307/3802658

Tharme, A. P., R. E. Green, D. Baines, I. P. Bainbridge, and M. O'Brien. 2001. The effect of management for Red Grouse shooting on the population density of breeding birds on heatherdominated moorland. Journal of Animal Ecology 38:439-457. http://dx.doi.org/10.1046/j.1365-2664.2001.00597.x

Thirgood, S. J., S. M. Redpath, S. Campbell, and A. Smith. 2002. Do habitat characteristics influence predation on Red Grouse? Journal of Applied Ecology 39:217-225. http://dx.doi.org/10.1046/ j.1365-2664.2002.00711.x

Thirgood, S. J., S. M. Redpath, D. T. Haydon, P. Rothery, I. Newton, and P. J. Hudson. 2000a. Habitat loss and raptor predation: disentangling long- and short-term causes of Red Grouse declines. Proceedings of the Royal Society of London. Series B: Biological Sciences 267:651-656. http://dx.doi. org/10.1098/rspb.2000.1051

Thirgood, S. J., S. M. Redpath, P. Rothery, and N. J. Aebischer. $2000 b$. Raptor predation and population limitation in Red Grouse. Journal of Animal Ecology 69:504-516. http://dx.doi. org/10.1046/j.1365-2656.2000.00413.x

Thomas, L., S. T. Buckland, E. A. Rexstad, J. L. Laake, S. Strindberg, S. L. Hedley, J. R. B. Bishop, T. A. Marques, and K. P. Burnham. 2010. Distance software: design and analysis of distance sampling surveys for estimating population size. Journal of Applied Ecology 47:5-14. http://dx.doi.org/10.1111/ j.1365-2664.2009.01737.x

Thompson, D. B. A., A. J. MacDonald, J. H. Marsden, and C. A. Galbraith. 1995. Upland heather moorland in Great Britain: a review of international importance, vegetation change and some objectives for nature conservation. Biological Conservation 71:163-178. http://dx.doi.org/10.1016/0006-3207(94)00043-P

VSN International. 2015. GenStat for Windows, $18^{\text {th }}$ edition. VSN International, Hemel Hempstead, UK.

Warren, P., and D. Baines. 2007. Dispersal distances of juvenile radiotagged Red Grouse Lagopus lagopus scoticus on moors in northern England. Ibis 149:758-762. http://dx.doi.org/10.1111/ j.1474-919X.2007.00705.x

Warren, P., and D. Baines. 2011. Evaluation of the distance sampling technique to survey Red Grouse Lagopus lagopus scoticus on moors in northern England. Wildlife Biology 17:135-142. http://dx.doi.org/10.2981/10-085

Watson, A., and R. Moss. 2008. Grouse. Collins, London, UK.

Whittingham, M. J., and K. L. Evans. 2004. The effects of habitat structure on predation risk of birds in agricultural landscapes. Ibis 146:210-220. http://dx.doi.org/10.1111/j.1474-919X.2004.00370. $\mathrm{x}$

Wilcove, D. S., D. Rothstein, J. Dubow, A. Phillips, and E. Losos. 1998. Quantifying threats to imperiled species in the United States. Bioscience 48:607-615. http://dx.doi.org/10.2307/1313420

Wilson, A. M., M. Ausden, and T. P. Milsom. 2004. Changes in breeding wader populations on lowland wet grasslands in England and Wales: causes and potential solutions. Ibis 146:32-40. http://dx.doi.org/10.1111/j.1474-919X.2004.00371.x

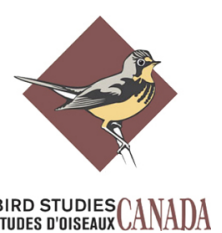




\section{Appendix 1.}

Table A1.1. Evaluation of effect of sampling regime on the precision of vegetation variables at the level of the data unit used for analysis of Grouse productivity and survival (Grouse home ranges and count blocks).

\begin{tabular}{|c|c|c|c|c|c|c|c|}
\hline \multirow[t]{2}{*}{ Unit type } & \multirow[t]{2}{*}{ Variable } & \multicolumn{2}{|c|}{$\begin{array}{l}\text { Between-unit } \\
\text { variation }\end{array}$} & \multicolumn{2}{|c|}{$\begin{array}{l}\text { Within-unit } \\
\text { variation }\end{array}$} & \multirow{2}{*}{$\begin{array}{c}\text { Contribution of } \\
\text { within-unit variation } \\
\text { to between-unit } \\
\text { variation }\end{array}$} & \multirow{2}{*}{$\begin{array}{c}\text { Mean } \\
\text { coefficient of } \\
\text { variation per } \\
\text { unit }\end{array}$} \\
\hline & & Units & $\begin{array}{c}\text { Stratum } \\
\text { variance }\end{array}$ & $\begin{array}{l}\text { Samples } \\
\text { per unit }\end{array}$ & $\begin{array}{c}\text { Stratum } \\
\text { variance }\end{array}$ & & \\
\hline Home ranges (summer) & Heather cover $(\%)$ & 92 & 2856.4 & 20 & 665.1 & $23 \%$ & $18 \%$ \\
\hline Home ranges (summer) & Management intensity (\%) & 92 & 346.2 & 20 & 137.4 & $40 \%$ & $58 \%$ \\
\hline Home ranges (summer) & Vegetation height $(\mathrm{cm})$ & 92 & 395.9 & 20 & 74.7 & $19 \%$ & $8 \%$ \\
\hline Home ranges (winter) & Heather cover $(\%)$ & 91 & 3912.6 & 20 & 569.7 & $15 \%$ & $20 \%$ \\
\hline Home ranges (winter) & Management intensity (\%) & 91 & 532.3 & 20 & 106.6 & $20 \%$ & $53 \%$ \\
\hline Home ranges (winter) & Vegetation height $(\mathrm{cm})$ & 91 & 471.5 & 20 & 90.2 & $19 \%$ & $9 \%$ \\
\hline Count blocks (2007) & Heather cover $(\%)$ & 10 & 1.922 & 50 & 0.206 & $11 \%$ & $18 \%$ \\
\hline Count blocks (2007) & Management intensity (\%) & 10 & 0.1609 & 50 & 0.0437 & $27 \%$ & $47 \%$ \\
\hline Count blocks (2007) & Vegetation density & 10 & 0.9256 & 50 & 0.1841 & $20 \%$ & $25 \%$ \\
\hline Count blocks (2012) & Heather cover $(\%)$ & 10 & 5.874 & 100 & 0.186 & $3 \%$ & $16 \%$ \\
\hline Count blocks (2012) & Management intensity (\%) & 10 & 0.3116 & 100 & 0.0303 & $10 \%$ & $52 \%$ \\
\hline Count blocks (2012) & Vegetation density & 10 & 2.393 & 100 & 0.215 & $9 \%$ & $8 \%$ \\
\hline Count blocks (2015) & Heather cover $(\%)$ & 10 & 6.754 & 100 & 0.191 & $3 \%$ & $11 \%$ \\
\hline Count blocks (2015) & Management intensity (\%) & 10 & 0.01156 & 100 & 0.00592 & $51 \%$ & $75 \%$ \\
\hline Count blocks (2015) & Vegetation density & 10 & 1.894 & 100 & 0.168 & $9 \%$ & $6 \%$ \\
\hline
\end{tabular}




\section{Appendix 2.}
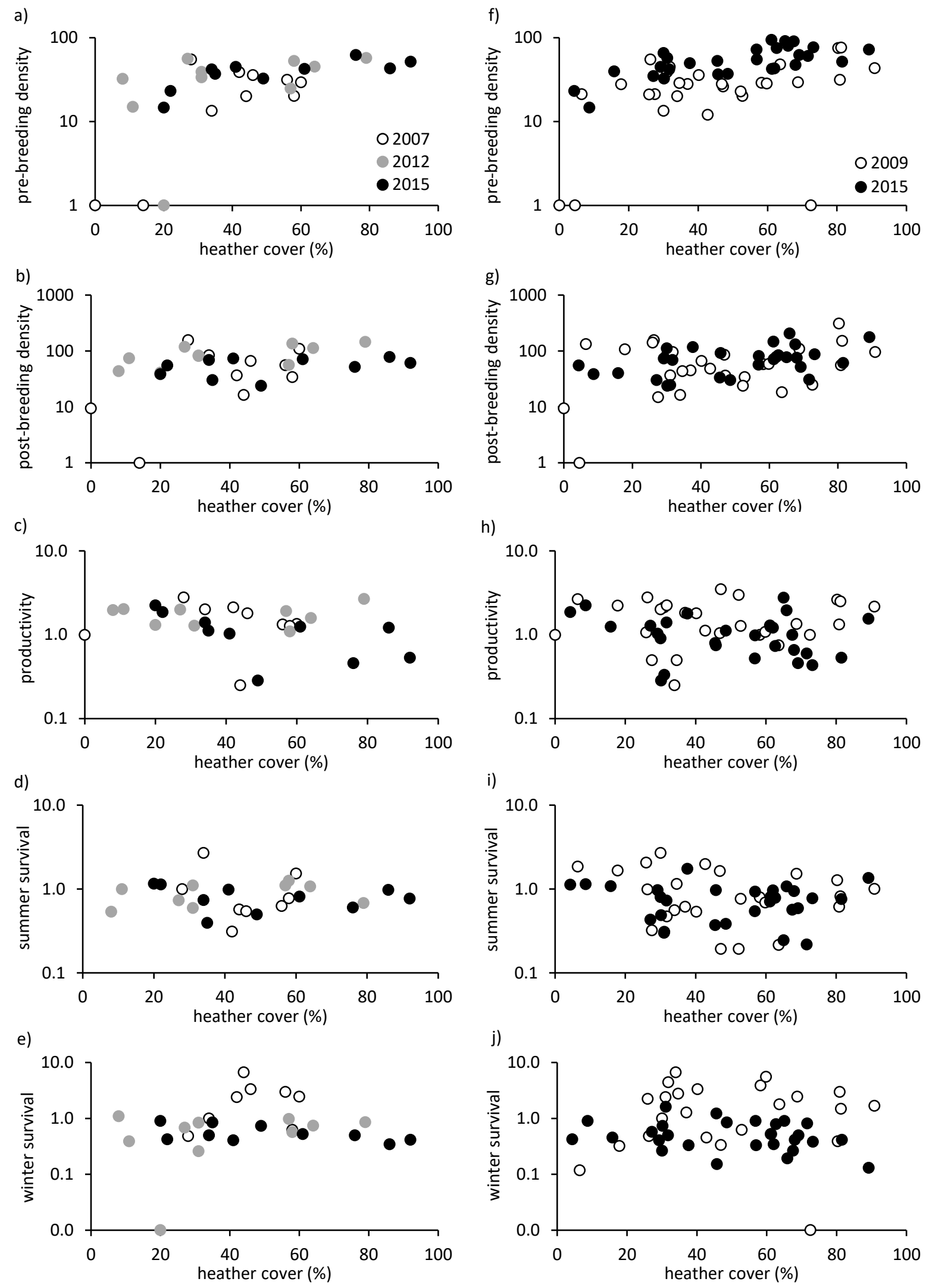

Figure A2.1. Relationships between Red Grouse demographic variables (on a logarithmic scale) and heather cover assessed during ground surveys (a-e) and aerial surveys (f-j). Note that the relationships between survival estimates and heather cover depicted here are not corrected for density dependence as in the respective models. 